\title{
Red Rice Agribusiness Strategy (Oryza nivara) In South Sulawesi Province
}

\author{
Munawarah1, Jusni2, Mahyuddin³, Didi Rukmana3 ${ }^{3}$ Nurjannah Hamid 2, Musran Munizu ${ }^{2}$ \\ ${ }^{1}$ Agribusiness Study Program Students, Postgraduate School of Hasanuddin University. Indonesia \\ ${ }^{2}$ Lecturer of Managemen Department of Hasanuddin University, Indonesia \\ ${ }^{3}$ Lecturer of Agribusiness Program, Postgraduate School of Hasanuddin University, Indonesia
}

Correspondence Author: Munawarah, Agribusiness Study Program Students, Postgraduate School of Hasanuddin University, Indonesia Email: munawarahmuna01@gmail.com

Received date: 29 August 2019, Accepted date: 28 October 2019, Online date: 30 October 2019

Copyright: (c) 2019 Munawarah., This is an open-access article distributed under the terms of the Creative Commons Attribution License, which permits unrestricted use, distribution, and reproduction in any medium, provided the original author and source are credited.

\section{ABSTRACT}

This study aims to analyze alternative strategies that can be applied in the development of red rice agribusiness in South Sulawesi Province, identify strategic issues of red rice agribusiness by looking at internal and external conditions and formulate alternative strategies in developing red rice agribusiness in South Sulawesi Province. The method used in this research is descriptive analysis, IFE and EFE analysis and SWOT analysis.

The results of the analysis show that the alternative strategies for developing red rice agribusiness in South Sulawesi Province that can be done to develop red rice agribusiness include: 1) Increasing Red Rice Production, 2) developing Marketing Areas, 3) Optimizing the Potential of Natural Resources, Human Resources and Existing Equipment Resources, 4) Creating and Developing Rice Production and Processing Technology, 5) Developing Farmers and Extension Workers for Cultivation and Processing of Red Rice, 6) Organizing Routine Meetings that Bridges Government and Farmer / Group Programs and Home Industry Programs, 7 ) Increasing the Quantity and Role of Farmer Groups, 8) Improving the Quality of Farmers' Knowledge and Knowledge through Education and Training, 9) Coordinating and Collaborating Between Farmers, Providers of Production Facilities, Traders, Home Industry and Financial Lembanga, 10) Strengthening Government Policy Regarding Determination Base Prices And Interest Rates Kr edit, 11) Creating a Special Region for Red Rice Cultivation, 12) Increasing the Use of Organic Fertilizers and Pesticides and Environmentally Friendly Equipment. The use of the 12 alternative strategies listed above will surely lead to an increase in the development of red rice in South Sulawesi Province.

Keywords: Development Strategy, SWOT Matrix, Red Rice.

\section{INTRODUCTION}

The agriculture sector plays a vital role in stabilizing the economic bases of developing countries. Since the agriculture sector is crucial in providing food needs of the population, supplying the raw material for industries, employment, and income generation, sustainability and stability of agriculture sector is among the major factors contributing to social stability and economic growth of the society[1]

The agricultural development paradigm is the realization of a healthy, productive, and creative society through resilient agriculture based on local resources [2]. Rice is the main food source for the Indonesian population. In the field of national food security, rice (processed rice) is a strategic commodity that has a major contribution to the social, economic, political and safety aspects of the Indonesian nation. As the main food ingredient, rice has contributed more than 55\% to energy needs and protein consumption of the community. One way to increase food production is to increase the harvest area [3]. Fulfilment of the use of rice seeds in rice cultivation requires superior varieties of certified seeds[4]. The rapid growth of the human population underlies many environmental problems. Environmental problems cannot be solved, except for human population problems that can be overcome and which have to do with the number of people on planet Earth who support the environment to meet their needs [5]. To make this happen, self-sufficiency in food is needed [6].

Rice production in South Sulawesi Province in 2017 increased by 108,282 tons from the previous year which reached $5,426,097$ tons in 2016 to $5,534,379$ tons in 2017 . The contribution of rice production in the province of South Sulawesi in 2017 amounted to 7.38 percent National rice production. The ideal conditions for growing rice have a considerable influence on other commodities. When the land was used for rice, other crops experienced a decline in both harvested area and production. Until now, agricultural management is still managed traditionally so that climatic conditions greatly influence the production results. [7] 
One of the food commodities that has a strategic and vital role in Indonesian society especially in South Sulawesi Province is rice. Rice aside from being a staple food, its existence is quite abundant and very easy to reach in all levels of Indonesian society. Rice production in Indonesia is actually very diverse types and varieties including red rice.

Red rice is one type of rice in Indonesia that contains high nutrition. Based on the results of research, red rice has a higher efficacy compared to white rice. The content of antithyrin in red rice can be an antioxidant to prevent diseases such as coronary heart disease, cancer, diabetes and hypertension. Nutritional composition of red rice per 100 grams consists of 7.5 grams of protein, 0.9 grams of fat, 77.6 grams of carbohydrates, 16 milligrams of calcium, 163 grams of phosphorus, 0.3 grams of iron, and 0.21 grams of vitamin B1, Consumption of red rice without refining it turns out to contain a lot of fiber, natural oils, and fats [8]. Based on research by Rui Hai Liu in Purwasasmita and Sudrajat (2014) [9], red rice is also stored in a variety of anti-cancer substances, including fiber, selenium, and phytochemical compounds such as phenolics and lignans.

Table 1. Rice Nutritional Content.

\begin{tabular}{lcccc}
\hline \multirow{2}{*}{ Type of rice } & Protein & Iron & Zink & Fiber \\
& $(\mathrm{g} / 100 \mathrm{~g})$ & $(\mathrm{mg} / 100 \mathrm{~g})$ & $(\mathrm{mg} / 100 \mathrm{~g})$ & $(\mathrm{g} / 100 \mathrm{~g})$ \\
\hline White rice & 6,8 & 1,2 & 0,5 & 0,5 \\
Red rice & 7,0 & 5,5 & 3,3 & 3,3 \\
\hline
\end{tabular}

Source: Association of Southeast Asian Nations (ASEAN) in Trubus: 2013.

Red rice has a higher selling value when compared to white rice and glutinous rice. This rice also has more advantages and benefits when compared to other rice. The process of planting and harvesting red rice is almost the same as white rice. Red rice farming in South Sulawesi Province is still relatively new while this red rice has the potential to be developed besides that the demand for red rice is increasing and the community as consumers are increasingly aware of health. Therefore research is needed to be carried out on "Red Rice Agribusiness Development Strategy (Oryza Nivara) in South Sulawesi Province. "

\section{RESEARCH METHODS}

The study was conducted in the area of South Sulawesi Province. This research was conducted by purposive sampling, with the location requirements being the development of the red rice commodity. This research has been carried out for \pm 3 months from November to December 2019.

The sample in this research is all actors involved in the strategy of developing red rice agribusiness in South Sulawesi Province, in this case, called informants. According to Faisal (2010) [10], that the concept relating to informants is how to choose informants or certain social situations that can provide steady and reliable information about elements that already exist so as to determine key informants (Key Informants) or certain social conditions. which is full of information in accordance with the focus of research to select key informants carried out deliberately (purposive sampling).

The data obtained are primary and secondary data which are processed by quantitative and qualitative methods. In this study, the analysis that will be used is descriptive analysis, IFE and EFE analysis and SWOT analysis.

In this rice agribusiness development research, there are two parties, namely external and internal parties. Internal parties in this study are the actors in the on-farm subsystem, namely red rice farmers. On the other hand, the external in this study was divided into two, namely the external task and the external remote. The external task force consists of (1) upstream subsystem actors, namely the nursery industry and providers of production facilities; (2) marketing subsystem actors, namely suppliers (traders) and consumers of red rice; (3) downstream (processing) subsystem actors, namely the red rice processing industry; and (4) subsystem of supporting institutions, namely financial institutions while the external remote is the provincial government at the research location.

\section{RESULTS AND DISCUSSION}

\section{Alternative Strategies in Red Rice Development in South Sulawesi Province A. Matriks IFE dan EFE}

In general, to analyze the supporting and inhibiting factors in the development of red rice agribusiness, internal and external factors that influence the development of red rice agribusiness in the South Sulawesi Province are used. Red Rice agribusiness development in South Sulawesi Province is highly dependent on internal and external conditions in farming that start from upstream to downstream as objects to be developed. For this reason, it is necessary to analyze the potential for developing red rice agribusiness in South Sulawesi Province and the necessary policy support.

1. Identification of Internal Factors

Identification of internal factors is carried out to determine the strengths and weaknesses faced in the process of developing Red Rice agribusiness in South Sulawesi Province. Based on these results, the strengths and weaknesses of the potential development of red rice agribusiness in South Sulawesi Province can be summarized in the following table: 
Citation: Munawarah et al., 2019. Red Rice Agribusiness Strategy (Oryza Nivara) In South Sulawesi Province. Advances in Environmental Biology., 13(10).66-72. DOI:10.22587/aeb.2019.13.10.9

Table 2. Internal Factors of Red Rice Agribusiness Development in South Sulawesi Province

\begin{tabular}{|ll|ll|}
\hline \multicolumn{2}{|c|}{ INTERNAL FACTORS } \\
\hline \multicolumn{2}{|c|}{ strengths (S) } & \multicolumn{1}{c|}{ weakness (W) } \\
\hline 1. & Availability of Certified Local Seeds & 1. & The Price Is Determined By The Trader \\
2. Soil, Weather and climate conditions & 2. & Quantity and Quality of Agricultural \\
3. Good quality red rice & & Extension Workers \\
4. & Business Motivation & 3. & Small Red Rice Farmer Groups \\
5. High Demand & 4. & Red Rice Processing Home Industry \\
6. & The productivity of Red Rice & 5. Red rice processing technology \\
7. & Business Experience & 7. & Farmer's Capital \\
& & & \\
& & & \\
& &
\end{tabular}

\section{Source: Primary Data After Processing, 2019.}

From the analysis of the above table shows the internal factors of the potential development of red rice agribusiness in South Sulawesi Province, which consists of strengths and weaknesses. There are seven strength factors and seven weaknesses factors that have been identified.

2. Identification of External Factors.

Identification of external factors is carried out to determine opportunities and threats in the development of red rice agribusiness in South Sulawesi Province which can be seen in the table below:

Table 3. External Factors of Red Rice Agribusiness Development in South Sulawesi Province.

\begin{tabular}{|c|c|}
\hline \multicolumn{2}{|c|}{ EXTERNAL FACTORS } \\
\hline Opportunities (O) & Threats (T) \\
\hline 1. Very High Market Demand & 1. Increased Land Conversion \\
\hline 2. Availability of Production Facilities & 2. High Pest Attack \\
\hline 3. Government Policy Support & 3. Prices of Relatively Expensive \\
\hline 4. Water Availability & Production Facilities \\
\hline 5. Trade between Regions & 4. Credit Facility Difficulties \\
\hline
\end{tabular}

Source: Primary Data After Processing, 2019.

From the results of the analysis of the table above shows the external factors potential for developing red rice agribusiness in South Sulawesi Province consisting of opportunities and threats. There are five factors that become opportunities and four weaknesses that have been identified. 3. Weighting and Assessment Methods for the IFE Matrix.

Internal Factor Evaluation (IFE) matrix is a strategic management tool to determine the results of an internal evaluation of the development of red rice agribusiness in South Sulawesi Province.

Table 4. Internal Factor Evaluation (IFE) Matrix for Red Rice Agribusiness Development in South Sulawesi Province

\begin{tabular}{|c|c|c|c|}
\hline Internal Factors & Weight & Rating & $\begin{array}{c}\text { Weight } x \\
\text { Rating }\end{array}$ \\
\hline 1 & 2 & 3 & $4=2 \times 3$ \\
\hline
\end{tabular}

\section{Strengths (S)}

\section{Upstream Agribusiness Subsystem (Upstream)}

1. Use of Certified Local Seeds

2. Suitability of soil, weather and climate conditions

\section{Production Subsystem (OnFarm)}

3. Quality of Red Rice is Good

4. Farmers' Motivation Is Very Strong For forwarding

5. Red Rice Productivity Is Quite High

6. Farmers have long experience in farming

$\begin{array}{lll}0,07 & 3,80 & 0,27 \\ 0,07 & 3,90 & 0,27 \\ 0,07 & 3,70 & 0,26 \\ 0,09 & 3,90 & 0,35\end{array}$

Agricultural Product Marketing Subsystem

7. Red rice is in great demand by consumers who suffer from diabetes 
1. Farmer's Capital

$$
0,08
$$

1,90

0,15

\section{Downstream Agribusiness Subsystem (Downstream)}
2. Processing Home Industry
0,07
0,07
1,90
0,13
3. Red Rice Processing Technology
0,07
1,90
0,13
4. Low Quality of Processed Products
0,06
1,80
0,11

Agricultural Product Marketing Subsystem

5. Prices Determined By Traders

0,07

1,80

0,13

Support Institution Subsystem

6. Quantity and Quality of Agricultural Extension Workers

\begin{tabular}{rrr}
0,06 & 2,00 & 0,12 \\
0,06 & 2,00 & 0,14 \\
$\mathbf{0 . 4 7}$ & & $\mathbf{0 , 9 1}$ \\
$\mathbf{1}$ & & $\mathbf{2 , 9 3}$ \\
\hline
\end{tabular}

7. Red Rice Farmer Groups Still Little

Total Weaknesses (Weakness)
Total Keseluruhan

1

2,93

Source: Primary Data After Processing, 2019.

The results of the analysis of internal factors in the table above show that the strength possessed in the development of red rice agribusiness in South Sulawesi Province lies in the experience of farming for a long time, while what has considered a weakness is the farmer's capital which is still very limited. This is indicated in the high rating level for strengths and a low rating for weaknesses. But in general, the development of red rice agribusiness in South Sulawesi Province is in a strong internal position, as evidenced by the total score being above 2.50 which is 2.93 .

4. Weighting and Evaluation for the EFE Matrix

The External Factor Evaluation (EFE) matrix is a strategic management tool for evaluating opportunities and threats that affect the development of red rice agribusiness in South Sulawesi Province.

Table 5. External Matrix of Evaluation Factors (EFE) Development of red rice agribusiness in South Sulawesi Province

\begin{tabular}{|c|c|c|c|}
\hline External Factors & Weight & Rating & $\begin{array}{c}\text { Weigt X } \\
\text { Rating }\end{array}$ \\
\hline 1 & 2 & 3 & $4=2 \times 3$ \\
\hline \multicolumn{4}{|l|}{ Opportunities (O) } \\
\hline \multicolumn{4}{|c|}{ Upstream Agribusiness Subsystem (Up Stream) } \\
\hline 1. Availability of Production Facilities & 0,12 & 3,80 & 0,46 \\
\hline 2. Water availability & 0,13 & 3,90 & 0,51 \\
\hline \multicolumn{4}{|c|}{ Downstream Agribusiness Subsystem (Out Stream) } \\
\hline 3. Very High Market Demand & 0,09 & 3,80 & 0,34 \\
\hline 4. Regional Trade & 0,12 & 3,80 & 0,46 \\
\hline \multicolumn{4}{|l|}{ Support Institution Subsystem } \\
\hline 5. Government Policy Support & 0,10 & 3,70 & 0,37 \\
\hline \multicolumn{4}{|l|}{ Threats $(\mathbf{T})$} \\
\hline \multicolumn{4}{|l|}{ Upstream Agribusiness Subsystem (Up Stream) } \\
\hline 1. Increased Land Conversion & 0,09 & 1,90 & 0,17 \\
\hline 2. The Price of Production Facilities is Relatively Expensive & 0,12 & 2,00 & 0,24 \\
\hline 3. Difficulties in Credit Facilities & 0,10 & 1,80 & 0,18 \\
\hline \multicolumn{4}{|c|}{ Downstream Agribusiness Subsystem (Out Stream) } \\
\hline 4. High Pest Attack & 0,13 & 1,90 & 0,25 \\
\hline Total Threats (T) & 0,44 & & 0,84 \\
\hline Total & 1 & & 2,98 \\
\hline
\end{tabular}

Source: Primary Data After Processing, 2019.

The results of the analysis of external factors in the table above show that the opportunity factor in developing red rice agribusiness in South Sulawesi Province lies in the availability of water, while the factor considered a threat is the high attack of red rice pests. This is indicated in the high rating level for opportunities and low ratings for threats. But in general, the development of red rice agribusiness in South Sulawesi Province is externally strong because the total score is above 2.50 which is 2.98 . 
Internal-external matrices or abbreviated IE matrices are based on the analysis of internal and external factors combined into one suggestive model. IE matrix is a continuation of the IFE and EFE matrices. The IE matrix is based on two criteria, namely the total weighting of internal factors (IFE) on the X-axis and the total weighting of external factors (EFE) on the Y-axis. In the IE model, the determination of strategy is determined based on the intersection of horizontal and vertical lines in nine cells on the IE matrix. The internal-external (IE) diagram for developing red rice agribusiness in South Sulawesi Province is as follows :

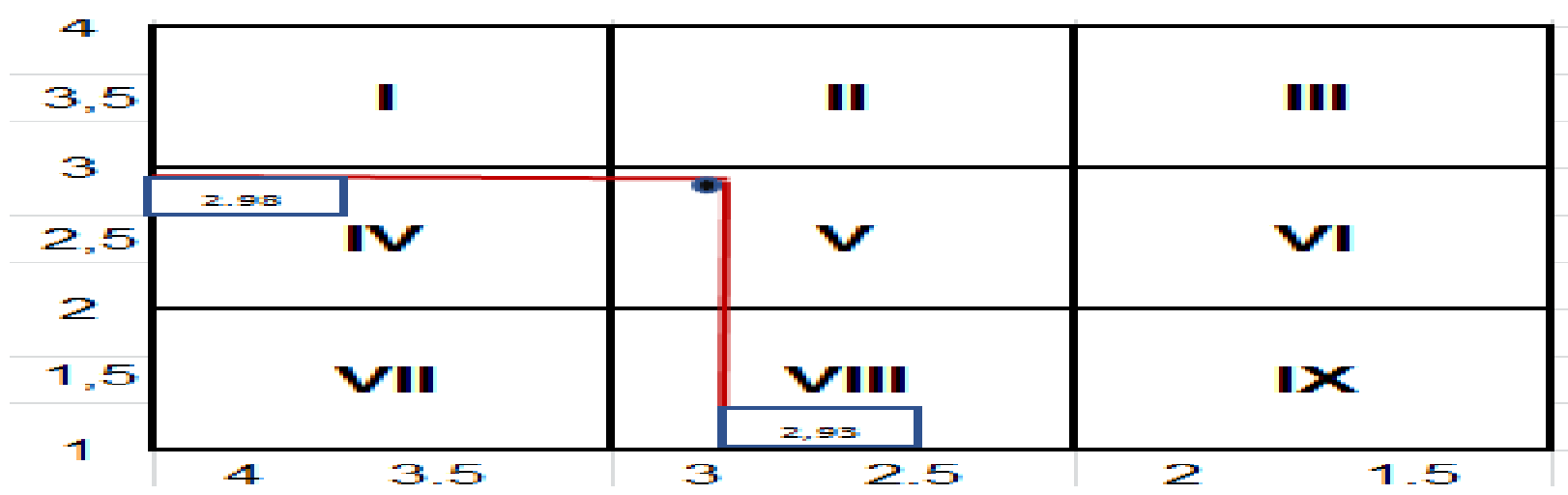

Figure 1. Matrix IE (Internal - External) Red Rice Agribusiness Development in South Sulawesi Province

From the picture, it can be seen that the position of developing red rice agribusiness in South Sulawesi Province is in cell $\mathrm{V}$ in the IE matrix. The strategy cell shows the strategy that should be carried out, namely maintaining and maintaining (hold and maintain strategies). This shows that the most feasible strategy is market penetration strategy and product development.

\section{SWOT analysis}

Based on IFAS and EFAS matrix calculations various alternative strategies can be formulated based on the SWOT matrix analysis model. The advantage of this model is that it is easy to formulate a strategy based on a combination of internal and external factors. The key to the success of the SWOT matrix is to bring together key internal and external factors to form a strategy. The SWOT matrix is a systematic identification of various factors to formulate a strategy. This matrix is based on logic that maximizes strengths and opportunities but simultaneously minimizes weaknesses and avoids threats (threaths). [11] The alternative formulation of strategies to those successfully analyzed for the development of red rice agribusiness in South Sulawesi Province can be seen in the following table:

Table 6. SWOT Matrix for Red Rice Agribusiness Development in South Sulawesi Province, 2019.

\begin{tabular}{|c|c|c|}
\hline & Strengths (S) & Weakness $(\mathrm{W})$ \\
\hline EXTERNAL & $\begin{array}{l}\text { S-1. Availability of Certified Local } \\
\text { seeds } \\
\text { S-2. Soil conditions, weather and } \\
\text { climate } \\
\text { S-3. Good Quality Red Rice } \\
\text { S-4. Business Motivation } \\
\text { S-5. High Demand } \\
\text { S-6. The productivity of red rice } \\
\text { S-7.Farmer's experience in farming }\end{array}$ & $\begin{array}{l}\text { W-1 Prices are determined by the } \\
\text { trader } \\
\text { W-2 Quantity and quality of } \\
\text { agricultural instructors } \\
\text { W-3 Small red rice farmer group } \\
\text { W-4 Home industry processing red } \\
\text { rice } \\
\text { W-5 Red rice processing } \\
\text { technology } \\
\text { W-6 Farmer's Capital } \\
\text { W-7 Low quality of processed } \\
\text { products }\end{array}$ \\
\hline Opportunity (O) & SO S & WO Strategy \\
\hline $\begin{array}{l}\text { O-1 High market demand } \\
\text { O-2 Availability of production } \\
\text { facilities } \\
\text { O-3 Government policy support } \\
\text { O-4 Availability of water } \\
\text { O-5. Trade between regions }\end{array}$ & $\begin{array}{l}\text { SO-1 Increases red rice production } \\
\text { (S3, } \\
\text { S4, S5, S6, S7, O1, O2) } \\
\text { SO-2 Develop marketing areas (S1, } \\
\text { S2, S4, S6, } \\
\text { S7, O1, O2) } \\
\text { SO-3. Optimizing the potential of } \\
\text { natural resources, human } \\
\text { resources and existing } \\
\text { equipment resources ( }(\mathrm{S} 1, \mathrm{~S} 2,\end{array}$ & $\begin{array}{l}\text { WO-1 Creates and Develops } \\
\text { technology for producing and } \\
\text { processing red rice (W2, W3, } \\
\text { W5, W6, W7, O1, O2) } \\
\text { WO-2 Guides farmers and extension } \\
\text { agents for the cultivation and } \\
\text { processing of red rice (W1, } \\
\text { W2, W3, W5, W6, O1, O2) } \\
\text { WO-3 Hold regular meetings that } \\
\text { bridge the government and } \\
\text { farmer/group programs and } \\
\text { home industries (W1, W2, } \\
\text { W3, W5, W6, O1, O2) }\end{array}$ \\
\hline
\end{tabular}




\begin{tabular}{|c|c|c|}
\hline & S3, S4, S5, S6, S7, O1, O2) & $\begin{array}{l}\text { WO-4 Increases the quantity and } \\
\text { role of farmer groups (W1, } \\
\mathrm{W} 2, \mathrm{~W} 3, \mathrm{~W} 5, \mathrm{~W} 6, \mathrm{O} 1, \mathrm{O} 2 \text { ) }\end{array}$ \\
\hline Threats (T) & ST Strategy & WT Strategy \\
\hline $\begin{array}{l}\text { T-1 Increased land conversion } \\
\mathrm{T}-2 \text { High pest attack } \\
\mathrm{T}-3 \text { The price of production } \\
\text { facilities is relatively } \\
\text { expensive } \\
\mathrm{T}-4 \text { Difficulties in credit } \\
\text { facilities }\end{array}$ & $\begin{array}{l}\text { ST-1Improve the quality of } \\
\text { farmers' knowledge and } \\
\text { knowledge through education } \\
\text { and training. (S1, S2, S4, S6, } \\
\text { S7, T1) } \\
\text { ST-2 Create a particular area for } \\
\text { red rice cultivation ( S2, S3, } \\
\text { S4, S5, T1) } \\
\text { ST-3 Increase the use of organic } \\
\text { fertilizers and pesticides and } \\
\text { environmentally-friendly } \\
\text { equipment (S3, S4, S5, S6, } \\
\text { S7, T1) }\end{array}$ & $\begin{array}{l}\text { WT-1 Conduct coordination and } \\
\text { cooperation between } \\
\text { farmers, providers of } \\
\text { production facilities, traders, } \\
\text { home industries and } \\
\text { financial institutions (W1, } \\
\text { W2, W3, W4, W5, W6, T2) } \\
\text { WT-2 Strengthens government } \\
\text { policies on setting base } \\
\text { prices and lending rates } \\
\text { (W1, W2, W3, W4, W5, } \\
\text { W6, T2) }\end{array}$ \\
\hline
\end{tabular}

ource: Primary Data After Processing, 2019.

Analysis of Table 6. shows that the performance of red rice agribusiness in South Sulawesi Province can be determined by a combination of internal and external factors. The combination of these two factors is shown in the results of the SWOT analysis as follows:

\section{SO Strategy (Supporting Aggressive Strategies)}

This strategy is based on the farm's way of thinking, namely by utilizing all the power to seize and take advantage of maximum opportunities. SO strategies that can be pursued by Red Rice Farming in South Sulawesi Province, namely:

1. Increase red rice production

2. Develop a marketing area

3. Optimizing the potential of natural resources, human resources and existing equipment resources

2. ST Strategy (Supports Diversification Strategy)

Is a strategy in using the strength of farming owned to overcome threats. The ST Strategy that can be pursued by Red Rice Farming in South Sulawesi Province, namely:

1. Improving the quality of farmers' knowledge and knowledge through education and training.

2. Creating a special area for red rice cultivation.

3. Increasing the use of organic fertilizers and pesticides and environmentally-friendly equipment

3. WO Strategy (Supports Turn-Around Strategy)

This strategy is implemented based on the utilization of existing opportunities by minimizing existing weaknesses. The WO strategies that can be pursued by Red Rice Farming in South Sulawesi Province include:

1. Creating and developing technology for the production and processing of red rice

2. Coaching farmers and extension workers for the cultivation and processing of red rice

3. Hold regular meetings that bridge the government and farmer / group programs and home industries

4. Increase the quantity and role of farmer groups

\section{WT Strategy (Supports Defensive Strategies)}

This strategy is based on activities that are defensive and try to minimize existing weaknesses and avoid threats. WT strategies that can be pursued by Red Rice Farming in South Sulawesi Province include:

1. Coordinating and cooperating between farmers, providers of production facilities, traders, home industries and financial institutions.

2. Strengthening government policies on setting base prices and lending rates

Based on the results of the SWOT analysis, the development of Red Rice Agribusiness in South Sulawesi Province has strengths that can be used in certain strategies, utilizing appropriate opportunities and simultaneously minimizing or avoiding existing weaknesses and threats. This position is very beneficial for red rice agribusiness by improving the conditions above with capability.

\section{CONCLUSION}

From the results of the discussion it can be concluded that the Alternative Strategy for developing red rice agribusiness in South Sulawesi Province that can be done to develop red rice agribusiness is to include: 1) Increasing Red Rice Production, 2) developing Marketing Areas, 3) Optimizing Potential of Natural Resources, Human Resources and Existing Equipment Resources, 4) Creating and Developing Rice Production and Processing Technology, 5) Fostering Farmers and Extension Workers for Cultivation and Processing of Red Rice, 6) Conducting Regular Meetings that Bridges Government and Farmer / Group Groups and Industry Programs Households, 7) Increasing Quantities and Role of Farmer Groups, 8) Improving the Quality of Farmers' Knowledge and Knowledge through Education and Training, 9) Coordinating and Collaborating Between Farmers, Providers of Production Facilities, Traders, Home Industry and Financial Institutions, 10) Strengthening Government 
Policy Regarding Basic Pricing $\mathrm{r}$ And Credit Interest Rates, 11) Creating Special Areas for Cultivation of Red Rice, 12) Increasing the Use of Organic Fertilizers and Pesticides and Environmentally Friendly Equipment. The use of the 12 alternative strategies listed above will surely lead to an increase in the development of red rice in South Sulawesi Province.

\section{REFERENCE}

[1] Neda Jowkar, Nematolah Masovi dan Bahaedine Najafi, 2015. Management Strategy For Agicultural Develovment in the Khaerameh City Using SWOT Model. AENSI Journals. Advances in Environmental Biology, 10(6): 839-846. ISSN-1816-9112

[2] Sirajuddin, S. N., Siregar, A. R., Nurlaelah, S., Lestari, V. S., \& Tenrisanna, V. (2017). The limitations and benefits of partnership sharing system of Corporated Cattle Market (CCM). American-Eurasian Journal of Sustainable Agriculture, 11(1), 11-15.

[3] Komala, D, R., N, Parining, I, W. Widyantara., 2019. Effectiveness of Irrigation Water Distribution System in Enhancing Rice Cropping Index at SubakPadanggalak, Kedewatan Irrigation Area, Bali /American-Eurasian Journal of Sustainable Agriculture. 13(2): 48-54.DOI: 10.22587/aejsa.2019.13.2.5.

[4] Unggul Budi Kusuma, Jusni dan Musran Munizu, 2019. Analysis Of Marketing Strategy Of Certified Rice Seeds (Case Study Of Pt. Sang Hyang Seri (Persero) Regional Vi Business Unit Sidrap, South Sulawesi). AENSI Journals. Advances in Environmental Biology, 13(6): 27-31. ISSN-1995-0756 EISSN-1998-1066

[5] Yadollahi, Et al, 2014. Evaluation of Agricultural Management and Physical - Chemical Soil Characteristics on Diversification of Weed Species in Farms, Global journal of biodiversity science and management ISSN : 2074 0875 .

[6] Prasekti. 2015. Economic Analysis of Ciherang Rice Seed Breeder Business (in Tamanan Kelurahan Tulungagung District, Tulungagung District) Agribusiness Journal Faculty of Agriculture Unita Vol. 11 No. 13

[7] Central Statistics Agency (BPS). 2017. Development Analysis in South Sulawesi (2017). SulSel, BPS.

[8] Directorate of Nutrition, Ministry of Health, Republic of Indonesia, 2009, Nutrition for Human Health. Printing 6. Yogyakarta: Gadjah Mada UniversityPress.

[9] Rui Hai Liu in Purwasasmita and Sudrajat, 2014 Encouraging Future Entrepreneurs: The Effect of Entrepreneurship Course Characteristics on Entrepreneur Intention, Disertation of the University of the University of St. Gallen Irchel, Zurich

[10] Faisal, 2010. Determination of Research Informants. Raja Grafindo Persada. Jakarta

[11] Rangkuti, Freedy. 2009. SWOT Analysis of the Technique for Dissecting Business Cases. PT. Gramedia Main Library. Jakarta 